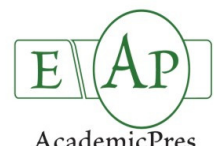

\title{
Modulation of the UV-B-induced Oxidative Stress and Apoptosis in HaCaT Cell Line with Calluna vulgaris Extract
}

\author{
Piroska VIRÁ G ${ }^{1 *}$, Ioana C. BRIE ${ }^{1}$, Claudia C. BURZ ${ }^{1,2}$, Corina B. TATOMIR ${ }^{1}$, \\ Tudor HODOR ${ }^{2}$, Remus ORĂSAN ${ }^{2,3}$, Hana P. DECEAN ${ }^{2,4}$ \\ 'The Oncology Institute "Prof.Dr.Ion Chiricuta", 3436Republicii, 400015 Chij-Napoca, Romania; vpiroska@yahoo.com ("corresponding author); \\ ioanabrie@yahoo.com;cburz@yahoo.fr;coratat@yahoo.com \\ 2"IuliuHatieganu"University of Medicine andPharmacy, 13Emil Isac,400023Chij-Napoca,Romania; tudor.hodor@gmailcom \\ ${ }^{3}$ ClinicofDermatology, 3-5Clinicilor, 400006Chij-Napoca,Romania;remus.orasan@umfchij.ro \\ ${ }^{4}$ EmergencyMilitaryHospitals,22TraianMosoiu,400132Chij-Napoca, Romania; hana_decean@yahoo.com
}

\begin{abstract}
The reactive oxygen species (ROS) production due to ultraviolet B (UV-B) exposure is extremely harmful to the skin. It causes lesions of DNA, proteins and lipids and leads to cellular death. In the present study the UV-B-induced ROS and subsequent apoptosis in the human keratinocyte cell line $(\mathrm{HaCaT})$ were counterbalanced by a plant extract with antioxidant capacity. Some molecules modulated by common heather (Calluna vulgaris) (CV) extract through which this may exert its photoprotective effects were also identified. The ROS were evaluated with CM- $\mathrm{H}_{2}$ DCFDA assay, while apoptosis and Bax$\alpha / \mathrm{Bcl}-\mathrm{xL}$ molecules with ELISA. The extract was standardized according to its polyphenolic content and the most important biologically active compounds, such as hyperozid, quercetin, isoquercetin, kampferol were evidenced by high-performance liquid chromatography. The UV-B induced ROS production occurred at its highest level at $2 \mathrm{~h}$ after the exposure of the $\mathrm{HaCaT}$ cells, while apoptosis later, at $4 \mathrm{~h}$. The most significant changes in Bax- $\alpha$ and Bcl-XL proteins induced by UV-B, as well as the highest effect of the extract on apoptosis, were both registered at $4 \mathrm{~h}$. The CV extract decreased concentration- and time-dependently the UV-B-induced ROS production and prevented apoptosis. These effects of CV occurred, at least to a certain extent, due to the modulation of $\mathrm{Bax}-\alpha / \mathrm{Bcl}-\mathrm{X}_{\mathrm{L}}$ proteins. These findings suggest that skin cells could be protected from some of the UV-B-induced harmful effects by the administration of the CV extract, which may be further exploited as a potential photoprotective agent.
\end{abstract}

Keywords: antioxidant capacity, apoptosis, Bax- $\alpha$, Bcl- $\mathrm{x}_{\mathrm{L}}$, common heather, $\mathrm{ROS}$

\begin{abstract}
Abbreviation list: Bak: a pro-apoptotic protein; $\mathrm{Bcl}-2$ homologous antagonist/killer; $\mathrm{Bax}-\alpha$ : a pro-apoptotic protein; $\mathrm{Bcl}-2$ homologous antagonist/killer; Bcl-2: B-cell lymphoma 2; member of the Bcl-2 family of proteins, anti-apoptotic; Bcl-x: B-cell lymphoma extra large; member of the Bcl-2 family of proteins, anti-apoptotic; ccK18: apoptosis-associated caspase-cleaved keratin 18; C: control (nonirradiated) group; CM-H2DCFDA: 5-(and-6)-chloromethyl-2',7'-dichlorodihydrofluorescein diacetate, acetyl ester; CV: Calluna vulgaris; CV1: Calluna vulgaris concentration $20 \mu \mathrm{g} \mathrm{EqGA} / \mathrm{ml}$; CV2: Calluna vulgaris concentration $40 \mu \mathrm{g} \mathrm{EqGA} / \mathrm{ml}$; DNA: deoxyribonucleic acid; DPPH: 2,2-diphenyl-1-picrylhydrazyl; EDTA: ethylenediaminetetraacetic acid; ELISA: enzyme-linked immunosorbent assay; EqGA: gallic acid equivalents; F.u.: Fluorescence units; HaCaT: human immortalized keratinocyte cell line; HRP: horseradish peroxidase; I: irradiated group; IC50: half maximal inhibitory concentration; K18Asp396 epitope: soluble caspase-cleaved fragments of the intermediate filament protein keratin 18 (K18) containing the M30 neo-epitope; KCs: Keratinocytes; M5: antibody, M5; M30: monoclonal antibody, M30; NAC: N-acetylcysteine; NP40: non-ionic polioxietilen-based surfactant solution; PBS: phosphate buffered saline; ROS: reactive oxygen species; SEM: standard error of the mean; U/L: Units/Liter; UV-B: ultraviolet B; UVR: ultraviolet radiation
\end{abstract}

Received: 29 June 2015. Received in revised form: 02 Sept 2015. Accepted: 10 Sept 2015. Published online: 10 Dec 2015. 
314

\section{Introduction}

Ultraviolet radiation (UVR), a high energy constituent of sunlight, is one of the most damaging environmental agents for the human skin. It causes alterations in the skin appearance, such as erythema, sunburn, hyper-pigmentation, photoaging or hyperplasia, immune suppression and DNA damage, which jointly can contribute to skin cancer induction (InYoung and Yu-Ying, 2014). UVR is a full carcinogen, being able to damage molecules (nucleic acids, proteins, lipids, saccharides) directly or indirectly through ROS production (Assefa et al., 2005). However, neither the source nor the pathways of these molecules generation after UVR are clearly understood. Although ultraviolet B (UV-B) radiation represents a smaller fraction of the UVR (4-5\%), it is harmful, causing sunburn and skin cancers (squamous and basal cell carcinoma) (Wu et al., 2015). UV-B exerts its deleterious effects due to the production of cyclobutane pyrimidine dimers and ROS (hydroxyl and peroxyl radicals, superoxide anion, singlet oxygen, hydrogenperoxide and ozone) by the irradiated skin cells (Janovska et al, 2015; Svobodova etal.,2003).

The ROS-induced photolesions are normally repaired or removed by cellular death (Salucci et al., 2014), according to the depth of the lesions and the repair capacity of the damaged cells. When the ROS production exceeds the skin's antioxidant defense capacity, a cascade of events is initiated resulting in inflammation, photoaging, abnormal gene expression and photocarcinogenesis (Sklar et al., 2013). The balance between these processes varies according to the dose of UVR, the cell type and the involved molecules $(\mathrm{Cu}, \mathrm{Zn}$ dismutases, catalase and heme oxygenase-1, gluthation S-transferase, inflammatory cytokines etc). Of great importance are the apoptosis regulatory proteins, such as antiapoptotic $\mathrm{Bcl}-2 / \mathrm{Bcl}-\mathrm{X}_{\mathrm{L}}$ and pro-apoptotic $\mathrm{Bax} / \mathrm{Bak}$ proteins, which exert their actions mostly at the level of mitochondria (Juba et al., 2013).

A practical approach to protect the human skin from these undesirable effects of UV-B and to reduce the severity of UV-Binduced skin diseases is to use active photoprotective agents. Besides the well-known compounds (vitamins C, E, beta-carotene etc), phenolics with documented antioxidative properties gained great interest being added to diet or used for topical applications (Lorencini M et al., 2014; Robbins, 2003). Biomaterials based on nanoparticles and natural extracts were tested recently as antiinflammatory agents, beneficial in treating skin diseases (David et al., 2014; Wu et al., 2015).

Calluna vulgaris L. Hull (CV), common heather belongs to Ericaceae family, a low-growing perennial shrub found widely in Europe and Asia Minor on acidic soils, was selected for investigations in the present study. Some of the CV extract's biological activities were assessed earlier on SKH-1 nude mice (Olteanu et al., 2012) and on umbilical vein endothelial cell line (Olteanu et al., 2014). These studies demonstrated beneficial effects, i.e. apoptosis prevention, evaluated through sunburn cells formation and on caspase 3 activation, respectively. Another finding revealed that the $\mathrm{CV}$ extract prevents the UV-B-induced DNA lesions in HaCaT cells (PerdeSchrepler et al.,2011).

The aim of the present study was to assess the potential protective effect of CV extract against the UV-B-induced ROS production and apoptosis in the human keratinocyte cell line $\mathrm{HaCaT}$. A secondary objective was to identify some molecules involved in apoptosis and through which the $\mathrm{CV}$ extract may exert its beneficial effects.

\section{Methods}

\section{Cell cultures}

The spontaneously transformed human keratinocytes cell line $(\mathrm{HaCaT})$ was purchased from the Cell Line Service of the German Cancer Research Centre in Heidelberg (Germany) (Boukamp et al., 1998). Cells were cultured in Dulbecco's Modified Eagle's Medium with $4500 \mathrm{mg}$ glucose. Media was supplemented with $10 \%$ Fetal Calf Serum and $1 \%$ Penicillin/Streptomycin. Cells were seeded in triplicate in 24-well plates at a cell population density of $125 \times 10^{3} /$ well. A plate was maintained as control and the others were irradiated with UV-B or treated with the plant extract and afterward irradiated with UV-B.

\section{$U V$-B irradiation of the cells}

The cells were washed and overlaid with a thin layer of Phosphate Buffered Saline and irradiated with Waldmann Medizintechnik UVB 181 broadband device (Waldmann $\mathrm{GmbH}$, Germany). This lamp, employed for therapeutical purposes, emits a continuous spectrum from 280 to $350 \mathrm{~nm}$, with a peak emission at $320 \mathrm{~nm}$, i.e preponderantly in UV-B (>91\%), this type of radiation ranging between $280-320 \mathrm{~nm}$. The emitted radiation dose was measured with a Variocontrol radiometer (Waldmann GmbH, Germany) before each experiment. Irradiation doses were calculated using the formula:

$$
\text { Dose }\left(\mathrm{mJ} / \mathrm{cm}^{2}\right)=\text { Exposure time }(\mathrm{sec}) \times \operatorname{Intensity}\left(\mathrm{mW} / \mathrm{cm}^{2}\right) \text {. }
$$

The UV-B's cytotoxicity on the HaCaT cells was previously determined (Perde-Schrepler et al., 2011) and the half maximal inhibitory concentration ( $\left.\mathrm{IC}_{50}\right)\left(217 \mathrm{~mJ} / \mathrm{cm}^{2}\right)$ was considered for the selection of the dose used in this study. Therefore, a dose within the physiological range of UVR exposure usually experienced by human skin and approximately equivalent to the minimal erythema dose (Pathak et al., 1987), was chosen $\left(100 \mathrm{~mJ} / \mathrm{cm}^{2}\right)$. Therefore, a plate was maintained as control and the others were irradiated with $100 \mathrm{~mJ} / \mathrm{cm}^{2} \mathrm{UV}-\mathrm{B}$ or treated with the plant extract and afterward irradiated with $100 \mathrm{~mJ} / \mathrm{cm}^{2} \mathrm{UV}-\mathrm{B}$.

\section{Morphology analysis}

The morphological analysis of the cells was performed using a light microscope (Carl Zeiss MicroImaging $\mathrm{GmbH}$, Gottingen, Germany), having digital photographic capability. The microscopic images of cells (non-irradiated; irradiated with UV-B; treated with the tested plant extract and afterward irradiated with UV-B) were compared with respect to morphological characteristics.

\section{Evaluation of the ROS production with $\mathrm{CM}-\mathrm{H}_{2} \mathrm{DCFD} \mathrm{A}$}

CM- $\mathrm{H}_{2} \mathrm{DCFDA}$, a chloromethyl derivative of $2^{\prime}, 7^{\prime}-$ dichlorodihydrofluorescein diacetate is a general oxidative stress indicator. Inside the cells it is cleaved by esterases and its chloromethyl group reacts with glutathione and other thiols, resulting in a fluorescent adduct. In the present study, the cells were seeded in triplicate in 24-well plates at a cell population density of $125 \times 10^{3} /$ well. After the cells' treatment CM$\mathrm{H}_{2}$ DCFDA was added to the wells $(10 \mu \mathrm{M})$ and the samples were incubated $30 \mathrm{~min}$ at $37^{\circ} \mathrm{C}$ and $5 \% \mathrm{CO}_{2}$ atmosphere. The fluorescence was recorded using Biotek Synergy 2, a multi-mode microplate reader (Winooski, USA), at $488 \mathrm{~nm}$. 

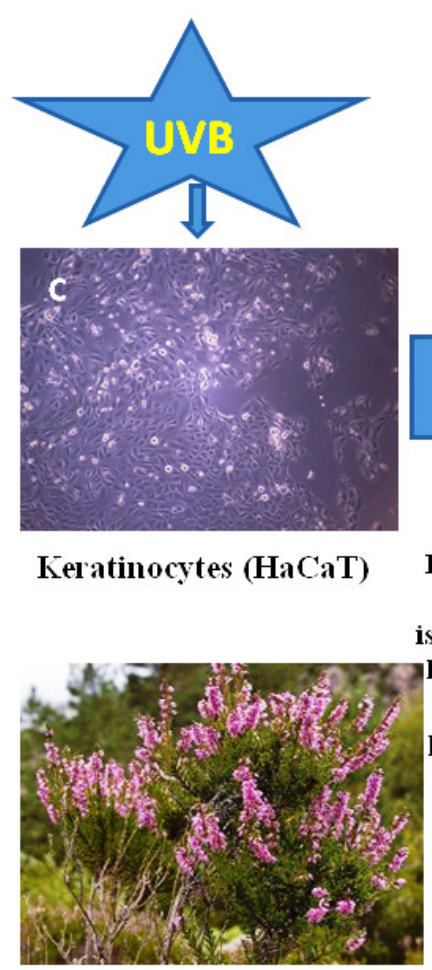

Common heather

(Calluna vulgatis L. Hull)
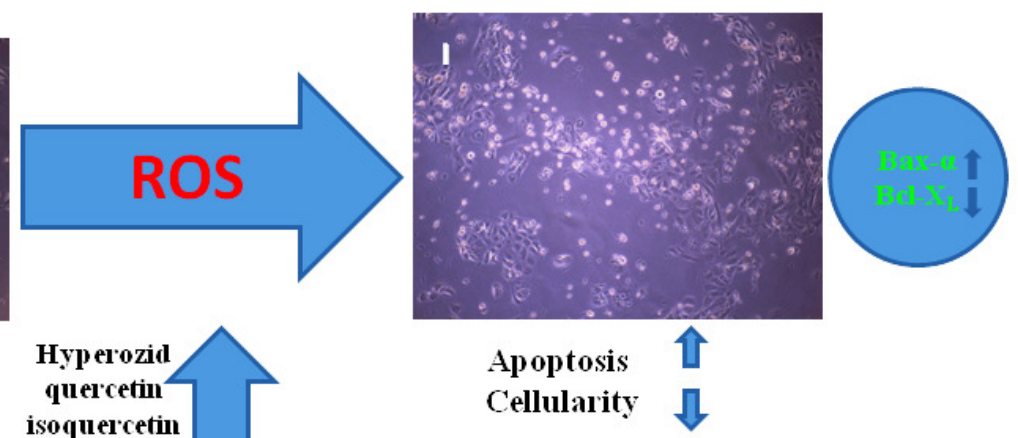

isoquercetio

kampferol

eulic and

p-cumaric

acids

rutozid

luteolin

Fig. 1. Microscopic images of the control HaCaT cells (C), cells irradiated with UV-B dose of $100 \mathrm{~mJ} / \mathrm{cm}^{2}(\mathrm{I})$ and cells treated with: $\mathrm{CV}_{1}(20 \mu \mathrm{EqGA} / \mathrm{ml})$ or $\mathrm{CV}_{2}(40 \mu \mathrm{EqGA} / \mathrm{ml})$ and afterward irradiated with a UV-B dose of $100 \mathrm{~mJ} / \mathrm{cm}^{2}\left(\mathrm{CV}_{1}+\mathrm{I} ; \mathrm{CV}_{2}+\mathrm{I}\right)$

\section{Detection of apoptosis with ELISA}

Apoptosis was assessed with M30 Apotosense ELISA solidphase sandwich enzyme immunoassay technique (PEVIVA, Bromma, Sweden), which quantitatively measures the apoptosisassociated caspase-cleaved keratin 18 (ccK18) in cell lysates, following the manufacturer's protocol. Briefly, cells were seeded in triplicate in 24-well plates at a cell population density of $125 \mathrm{x}$ $10^{3} /$ well, treated as described above and then incubated for 2,4 and $8 \mathrm{~h}$. The cells lysis was carried out with NP $4010 \%$, a nonionic polioxietilen-based surfactant solution. Cell lysates were added to a capture antibody M5 directed against ccK18. The secondary monoclonal antibody was represented by M30, directed against the K18Asp396 epitope. The absorbance was recorded at $450 \mathrm{~nm}$ with a microplate reader (Tecan Sunrise, Grödig/Salzburg, Austria).

Determination of the intracellular levels of $B a x-\alpha$ and $B c l-x_{L}$ with ELISA

$\mathrm{Bax}-\alpha$ and $\mathrm{Bcl}-\mathrm{x}_{\mathrm{L}}$ levels from the cell lysates were determined using sandwich-ELISA technique (R\&D Systems, Abingdon, UK), according to the manufacturer's indications. The cells were seeded in triplicate in 24-well plates at a cell population density of $125 \times 10^{3} /$ well and treated as described above. After 2, 4 and $8 \mathrm{~h}$ from UV-B exposure, the cells were lysed with a buffer based on $1 \mathrm{mM}$ EDTA, $0.005 \%$ Tween 20, 0.5\% Triton X-100, $10 \mu \mathrm{g} / \mathrm{ml}$ Leupeptin, $10 \mu \mathrm{g} / \mathrm{ml}$ Pepstatin, $100 \mu \mathrm{M}$ PMSF and $3 \mu \mathrm{g} / \mathrm{ml}$
Aprotinin in PBS, ph 7.2-7.4. Mouse anti-human and rat antimouse capture antibodies were used for $\mathrm{Bax}-\alpha$ and $\mathrm{Bcl}-\mathrm{xL}$ molecules, respectively. Biotinylated detection antibodies specific for these molecules were used in a standard streptavidin-HRP format. The fluorescence was recorded at $450 \mathrm{~nm}$ with a microplate reader (Tecan Sunrise, Grödig/Salzburg, Austria).

\section{Plantmaterial}

The raw material - the aerial part of the plant Calluna vulgaris - was collected on August 2010 in Ciucea rural area, Cluj County, Romania. The species was identified by Professor Mircea Tămaş from the University of Medicine and Pharmacy, Cluj-Napoca. A voucher specimen was deposited in the Herbarium of the Botanical Department of the same University (index number: 825). The plant extract was prepared according to previous descriptions (Filip et al., 2011; Postescu et al., 2007). Briefly, a fluid extract (1:1) was obtained from $30 \mathrm{~g}$ dry vegetal material in $300 \mathrm{ml} 70 \%$ ethanol, by maceration at room temperature for 1 week. The extract's total polyphenolic content was determined by Folin-Ciocalteu method (Postescu et al., 2007) and was standardized as $19 \mathrm{mg}$ gallic acid equivalents (GAE) $/ \mathrm{ml}$. Proanthocyanidins represented $3.15 \mathrm{mg} / \mathrm{ml}$ and monomer anthocyanins $5.81 \mathrm{mg} / \mathrm{ml}$. The most important biologically active compounds were evidenced by highperformance liquid chromatography which indicated the presence of hyperozid, quercetin, isoquercetin, kampferol and 
316

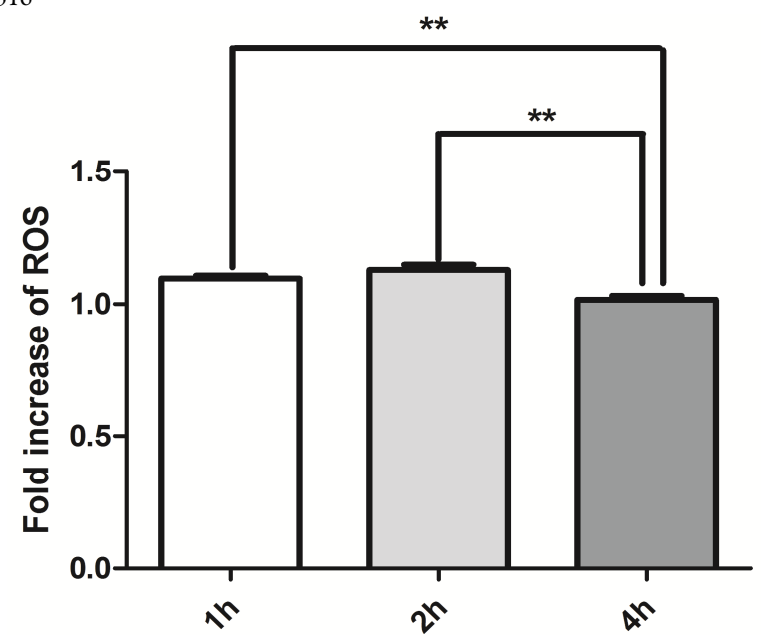

Fig. 2. Kinetics of ROS production in HaCaT cells exposed to UV-B radiation (at 1,2 and $4 \mathrm{~h}$ after irradiation). Values are expressed as fold changes of ROS in irradiated $v s$ control cells. Statistical comparisons between groups were made by Unpaired $t$ test, ${ }^{* *} \mathrm{p}<0.001$ (Means \pm SEM, $\mathrm{n}=3$ )

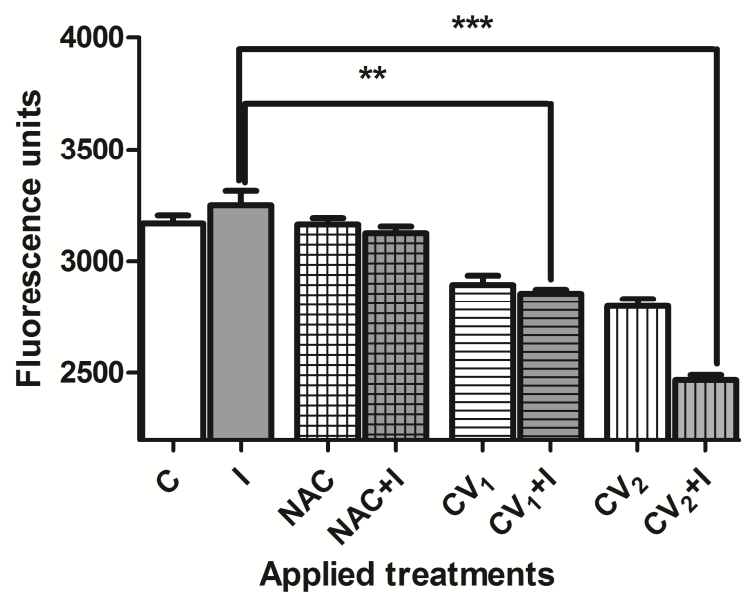

Fig. 3. The level of ROS production at $4 \mathrm{~h}$ after the following treatments of the HaCaT cells: control (C); irradiated with $100 \mathrm{~mJ} / \mathrm{cm} 2 \mathrm{UV}-\mathrm{B}$ (I); treated with $\mathrm{N}$-acetylcysteine $(5 \mathrm{mM})$ (NAC); treated with $\mathrm{N}$ acetylcysteine $(5 \mathrm{mM})$ followed by irradiation with $100 \mathrm{~mJ} / \mathrm{cm} 2 \mathrm{UV}-\mathrm{B}$ $(\mathrm{NAC}+\mathrm{I})$; treated with CV1 $(20 \mu \mathrm{EqGA} / \mathrm{ml})$; treated with CV1 $(20$ $\mu \mathrm{EqGA} / \mathrm{ml})$ followed by irradiation with $100 \mathrm{~mJ} / \mathrm{cm} 2 \mathrm{UV}-\mathrm{B}$ $(\mathrm{CV} 1+\mathrm{I})$; treated with CV2 $(40 \mu \mathrm{EqGA} / \mathrm{ml})$; treated with CV2 (40 $\mu \mathrm{EqGA} / \mathrm{ml}$ ) followed by irradiation with $100 \mathrm{~mJ} / \mathrm{cm} 2 \mathrm{UV}-\mathrm{B}(\mathrm{CV} 2+\mathrm{I})$. Statistical comparisons between groups were made by Unpaired t test, ${ }^{* *} \mathrm{p}<0.001 ;{ }^{* * *} \mathrm{p}<0.0001$ (Means \pm SEM, $\mathrm{n}=3$ )

smaller amounts of eulic and p-cumaric acids, rutozid and luteolin (Perde-Schrepler et al., 2011). The antioxidant activity of $\mathrm{CV}$ extract was established at $0.211 \pm 0.08 \mathrm{mM} / \mathrm{mM} 2,2-$ diphenyl-1-picrylhydrazyl (DPPH), respectively $38.92 \pm 0.01$ mM Trolox eq (Filipet al., 2011).

$\mathrm{N}$-acetylcysteine (NAC), a well-known selective inhibitor of ROS (Sun, 2010), was used ( $5 \mathrm{mM}$ ) as positive control.

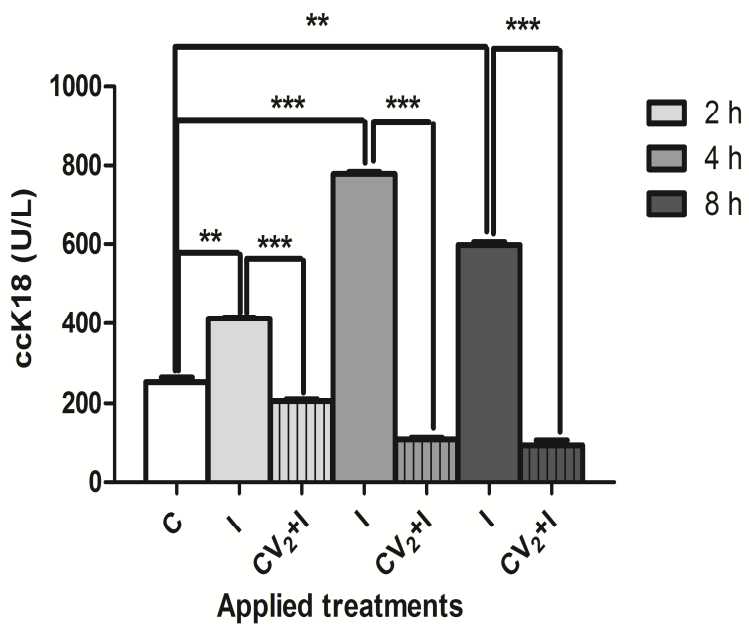

Fig. 4. Apoptosis production at $4 \mathrm{~h}$ after the following treatments of the $\mathrm{HaCaT}$ cells: control (C); irradiated with $100 \mathrm{~mJ} / \mathrm{cm}^{2} \mathrm{UV}-\mathrm{B}(\mathrm{I})$; treated with $\mathrm{CV}_{1}(20 \mu \mathrm{EqGA} / \mathrm{ml})$; treated with $\mathrm{CV}_{1}(20 \mu \mathrm{EqGA} / \mathrm{ml})$ followed by irradiation with $100 \mathrm{~mJ} / \mathrm{cm}^{2} \mathrm{UV}-\mathrm{B}\left(\mathrm{CV}_{1}+\mathrm{I}\right)$; treated with $\mathrm{CV}_{2}(40$ $\mu \mathrm{EqGA} / \mathrm{ml})$; treated with $\mathrm{CV}_{2}(40 \mu \mathrm{EqGA} / \mathrm{ml})$ followed by irradiation with $100 \mathrm{~mJ} / \mathrm{cm}^{2} \mathrm{UV}-\mathrm{B}\left(\mathrm{CV}_{2}+\mathrm{I}\right)$. Statistical comparisons between groups were made by Unpaired $t$ test, ${ }^{* *} \mathrm{p}<0.001,{ }^{* * *} \mathrm{p}<0.0001$ (Means \pm SEM, $\mathrm{n}=2$ )

Assessment of the plant extract's cytotoxicity on the $\mathrm{HaCaT}$ cells

The cytotoxicity of the CV extract on $\mathrm{HaCaT}$ cells was determined earlier (Perde-Schrepler et al., 2011), and the calculated $\mathrm{IC}_{50}$ value $(74.2 \mu \mathrm{g} \mathrm{EqGA} / \mathrm{ml})$ was considered as guide-mark for the tested concentrations. Aiming to identify protective effects concentrations in the non-toxic range were used, below the measured $\mathrm{IC}_{50}$ values. Therefore, the following concentrations were considered for testing: $\mathrm{CV}_{1}(20 \mu \mathrm{g}$ $\mathrm{EqGA} / \mathrm{ml})$ and $\mathrm{CV}_{2}(40 \mu \mathrm{g} \mathrm{EqGA} / \mathrm{ml})$. The cells were treated with the selected concentrations of the plant extract or with NAC ( $5 \mathrm{mM}$ ), used as positive control, for $30 \mathrm{~min}$ before 100 $\mathrm{mJ} / \mathrm{cm}^{2} \mathrm{UV}-\mathrm{B}$ irradiation.

\section{Statistical analysis}

Statistical processing of the experimental data was done using GraphPad Prism software program, version 5.0 (GraphPad, San Diego, CA, USA). Column statistics were performed, a method used with data entered on data tables formatted for Column data. The statistical comparisons between groups (two by two) were assessed by Unpaired $t$ test, at $\mathrm{p}<0.05$ statistical significance (control $v$ s irradiated; irradiated with UV-B radiation $v s$ treated with one of the concentration of the plant extract and afterward irradiated with UV-B radiation).

\section{Results}

Morphology analysis of $\mathrm{HaCaT}$ cells exposed to $U V-B$ radiation and/or treated with plant extract

The microscopic analysis revealed distinct features for the control cells as compared to UV-B-irradiated ones and to those previously treated with the plant extract and afterward irradiated with UV-B (Fig. 1). 
A

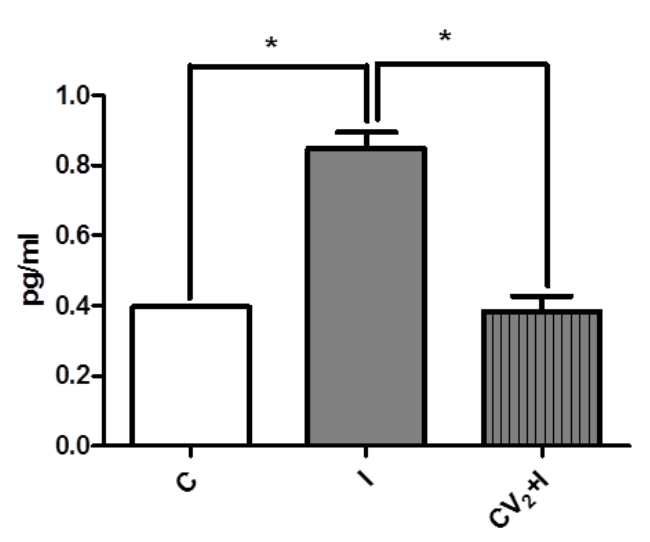

Applied treatments

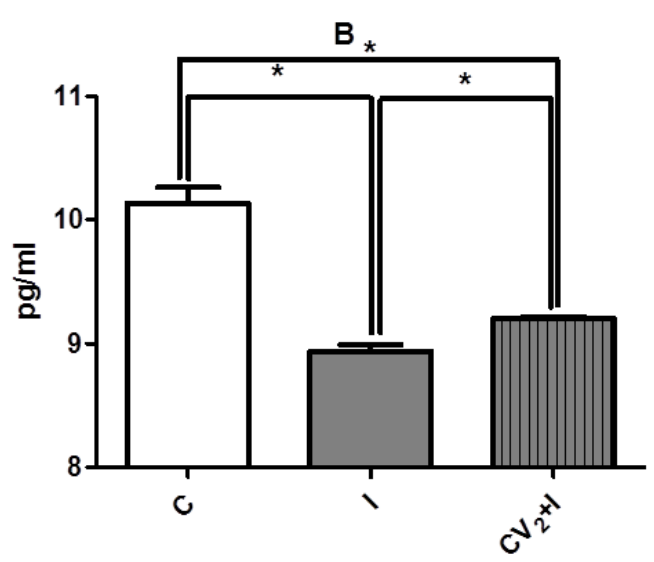

Applied treatments

Fig. 5. Expression of Bax- $\alpha(\mathrm{A})$ and $\mathrm{Bcl}-\mathrm{xL}(\mathrm{B})$ apoptosis regulatory proteins at $4 \mathrm{~h}$ after the following treatments of the $\mathrm{HaCaT}$ cells: control (C); irradiated with $100 \mathrm{~mJ} / \mathrm{cm}^{2} \mathrm{UV}-\mathrm{B}(\mathrm{I})$; treated with $\mathrm{CV}_{2}(40 \mu \mathrm{EqGA} / \mathrm{ml})$ followed by irradiation with $100 \mathrm{~mJ} / \mathrm{cm}^{2} \mathrm{UV}-\mathrm{B}\left(\mathrm{CV}_{2}+\mathrm{I}\right)$. Statistical comparisons between groups were made by Unpaired $t$ test, ${ }^{*} \mathrm{p}<0.05$ (Means $\pm \mathrm{SEM}, \mathrm{n}=2$ )

Thus, microscopy slides of $\mathrm{HaCaT}$ cells irradiated with UV-B showed decreased cellularity and elevated mass of apoptotic cells/total amount of cells, as compared to the controls. Conversely, slides representing cells treated with the plant extract and afterwards exposed to UV-B depicted higher cellularity and lower amount of apoptotic cells/total amount of cells, as compared to the solely irradiated ones. Their microscopic aspects i.e. cellularity and the occurrence of the apoptotic cells/total amount of cells, show similarity with the control cells.

The level of ROS produced in $\mathrm{HaCaT}$ cells exposed to $U V-B$ radiation and/or treated with $C V$ extract

The ROS production after exposing the cells to 100 $\mathrm{mJ} / \mathrm{cm}^{2}$ UV-B radiation was evaluated at several intervals ( 1 , 2 and $4 \mathrm{~h}$ ). The level of ROS was higher at early time points following UV-B exposure ( $1 \mathrm{~h}$ and $2 \mathrm{~h}$ ) resulting in 1.1 fold increase $v s$ control at $1 \mathrm{~h}$ and 1.13 at $2 \mathrm{~h}$, respectively. The differences between irradiated and control cells showed decreasing tendency at $4 \mathrm{~h}$. There were statistically significant differences between the magnitude of fold changes of ROS at $1 \mathrm{~h}$ and $2 \mathrm{~h} v s$ those determined at $4 \mathrm{~h}(\mathrm{p}<0,001$ in both cases) (Fig. 2).

None of the selected concentrations of the plant extract exerted ROS decreasing effects at 1 or $2 \mathrm{~h}$ after UV-B irradiation (data not shown). Conversely, the extract concentrations-dependently reduced the levels of ROS at $4 \mathrm{~h}$. For the $\mathrm{CV}_{1}$ extract the level of ROS induced by UV-B was reduced from 3249 \pm 112.6 Fluorescence units (F.u.) to $2855 \pm 30.92$ F.u. $(\mathrm{p}<0.001)$, corresponding to 1.13 fold reduction $v s$ solely irradiated cells. $\mathrm{CV}_{2}$ extract exerted a decrease in the level of ROS from $3249 \pm 112.6$ F.u. to $2468 \pm 39.63$ F.u. $(p<0.0001)$, corresponding to 1.31 fold decrease $v s$ control (Fig. 3.).

Compared to the results obtained with NAC (used as positive control), both concentrations of the plant extract had significantly superior ROS scavenging effects. NAC, a wellknown selective ROS inhibitor (used as positive control in this study) determined a slight reduction in ROS level at $4 \mathrm{~h}$, from $3249 \pm 112.6$ to $3125 \pm 50.21$ F.u. (Fig. 3 ), representing a 1.03 fold decrease $v s$ solely irradiated cells.
The level of the apoptosis induced by UV-B irradiation and/or treatment with $\mathrm{CV}_{2}$ extract in $\mathrm{HaCaT}$ cells

Apoptosis was evaluated in control cells, UV-B irradiated cells, and in cells previously treated with $\mathrm{CV}_{1}$ or $\mathrm{CV}_{2}$ and then irradiated, at three time points: $2 \mathrm{~h}, 4 \mathrm{~h}$ and $8 \mathrm{~h}$. The intracellular level of ccK18 was assessed to quantify the apoptosis. At $2 \mathrm{~h}$ the ccK18 level increased from $253 \pm 16.43 \mathrm{U} / \mathrm{L}$ to $411.8 \pm 4.43 \mathrm{U} / \mathrm{L}$ in the solely irradiated cells $(\mathrm{p}<0.001)$, corresponding to 1.62 fold increase $v$ s control. At $4 \mathrm{~h}, \mathrm{UV}-\mathrm{B}$ induced an important increase in the level of ccK18, to $778.4 \pm 7.6 \mathrm{U} / \mathrm{L}(\mathrm{p}<0.0001)$, corresponding to 3.07 fold increase $v$ s control. $8 \mathrm{~h}$ after irradiation the level of this protein was also increased but at a lower magnitude: $598.2 \pm 10.2$ $\mathrm{U} / \mathrm{L}(\mathrm{p}<0.001)$, which represents 2.36 fold increase $v s$ control. These data identify a peak level of apoptosis induction at $4 \mathrm{~h}$ after UV-B irradiation and a decreasing tendency after this time point (Fig. 4).

The highest ROS scavenging effect on UV-B irradiated $\mathrm{HaCaT}$ cells was produced by the higher concentration of the plant extract $\left(\mathrm{CV}_{2}\right.$ with $40 \mu \mathrm{gEqGA} / \mathrm{ml}$ concentration), therefore we tested this extract for its potential effects on apoptosis. $\mathrm{CV}_{2}$ determined a significant decrease in ccK18 level when administered previously to UV-B radiation for all three time points. The highest effect was registered $4 \mathrm{~h}$ after irradiation, the level of this protein decreasing from $778.4 \pm 7.6 \mathrm{U} / \mathrm{L}$ to $107.7 \pm 5.9$ $\mathrm{U} / \mathrm{L}(\mathrm{p}<0.0001)$, in the cells treated with this extract $v$ s solely irradiated cells corresponding to a 7.22 fold change (Fig. 4)

The levels of Bax- $\alpha$ pro-apoptotic and Bcl-xL anti-apoptotic proteins in $\mathrm{HaCa}$ cells after $U V-B$ irradiation and/or treatment with $\mathrm{CV}_{2}$ extract

Significant changes in the level of Bax- $\alpha$ (pro-apoptotic protein) in UV-B-exposed $\mathrm{HaCaT}$ cells were registered at $4 \mathrm{~h}$ after UV-B exposure, when the level of this molecule increased from $0.3965 \pm 0.0007 \mathrm{pg} / \mathrm{ml}$ to $0.8475 \pm 0.06 \mathrm{pg} / \mathrm{ml}(\mathrm{p}<0.05)$, corresponding to a 2.13 fold increase as compared to control. Administration of $\mathrm{CV}_{2}$ plant extract before irradiation significantly reduced the level of Bax- $\alpha$ protein: form $0.8475 \pm 0.06 \mathrm{pg} / \mathrm{ml}$ to $0.3825 \pm 0.06 \mathrm{pg} / \mathrm{ml}, \quad(\mathrm{p}<0.05)$, corresponding to 2.21 fold decrease $v s$ solely irradiated cells (Fig. 5.A). 
318

Conversely, Bcl-xL (anti-apoptotic protein) decreased at $4 \mathrm{~h}$ after UV-B irradiation: from $10.13 \pm 0.18 \mathrm{pg} / \mathrm{ml}$ to $8.93 \pm 0.07$ $\mathrm{pg} / \mathrm{ml}(\mathrm{p}<0.05)$, which represents 1.13 fold decrease $v s$ control. When cells were treated previously with $\mathrm{CV}_{2}, \mathrm{Bcl}-\mathrm{xL}$ protein decreased at $4 \mathrm{~h}$ after irradiation from $10.13 \pm 0.18 \mathrm{pg} / \mathrm{ml}$ to $9.19 \pm 0.02 \mathrm{pg} / \mathrm{ml}(\mathrm{p}<0.05)$, corresponding to 1.1 fold decrease $v$ s control (Fig. 5.B). This fold change was less important than that induced by UV-B irradiation alone $(9.19 \pm 0.02 \mathrm{pg} / \mathrm{ml} v$ s $8.93 \pm 0.07 \mathrm{pg} / \mathrm{ml}$ ), corresponding to a 1.02 fold difference between $\mathrm{Bcl}-\mathrm{xL}$ levels in cells treated or not with $\mathrm{CV}_{2}$ extract.

\section{Discussion}

The results in the present study showed that UV-B-induced cell death could be prevented by treating the cells with a plant extract having antioxidant properties. UV-B radiation influences a number of protein kinases, transcription factors and receptors, which may contribute to UVR-induced apoptosis (Kulms and Schwartz, 2002). Among these structures the central role is played by $\mathrm{Bax} / \mathrm{Bcl}$ proteins exerting pro- or anti-apoptotic roles (Juba et al., 2013).

In the present study, the outcome of exposing cells to UV-B radiation within the physiological range of UVR exposure and equivalent to the minimal erythema dose $\left(100 \mathrm{~mJ} / \mathrm{cm}^{2}\right)$ was a significant ROS production. The peak level of ROS, registered at $2 \mathrm{~h}$, is in accordance with other findings which demonstrated significantly higher rate of ROS production in the early time period after irradiation (0-2 h) (Dhumrongvaraporn and Chanvorachote, 2013; Masaki et al., 2009). The maximum level of apoptosis occurred later (at $4 \mathrm{~h}$ ), suggesting the implication of the radiation-induced ROS in this process. Other studies also demonstrated that ROS-mediated damages lead to lysosomal membrane rupture and consequent cell death in UV-Birradiated keratinocytes (KCs) (Boya, 2003; Zhao et al., 2000). However, neither the source of ROS generated in response to UV-B radiation nor the pathways by which they are generated in the skin are not entirely understood. Ryu et al. (2010) claim that a pathway linked to leukotriene $\mathrm{B}_{4}$ receptor BLT2 and NADPH oxidase family protein Nox1 might have a crucial role. Others sustain that intracellular $\mathrm{Ca}^{2+}$ (Masaki et al., 2009) or catalase enzyme in the skin (Heck et al., 2003) might be the trigger for UV-B-induced ROS generation.

According to the present study's results, apoptosis in UV-Bexposed $\mathrm{HaCaT}$ cells occurred due to a significant increase in the $\mathrm{Bax}-\alpha$ and to a decrease in $\mathrm{Bcl}-\mathrm{X}_{\mathrm{L}}$ proteins. $\mathrm{Bcl}-\mathrm{X}_{\mathrm{L}}$ protein is expressed in the upper layer of the epidermis (Krajevski, 1994) and it was shown to protect KCs against UV-B-induced cell death and against the formation of skin tumours in transgenic mice (Assefa et al., 2005). Its overexpression in human KCs blocked the UV-B-induced apoptosis both in vivo and in vitro (Takahashi, 2001) and acted as antioxidant and inhibitor of ROS generation (Hockenbery et al., 1993). In addition, this molecule was shown to prevent the disruption of the lysosomal and mitochondrial membranes, subsequently inhibiting Bax, the pro-apoptotic protein (Kane, 1993).

In the present study the treatment of the skin cells with the two concentrations of the CV extract prior to UV-B exposure diminished the level of ROS, as compared to the solely irradiated cells. Both apoptosis and the proteins related to this process (Bax$\alpha$ and $\left.\mathrm{Bcl}-\mathrm{X}_{\mathrm{L}}\right)$ were affected by the higher concentration of the extract $\left(\mathrm{CV}_{2}\right)$. The most pronounced effects on apoptosis and regulatory proteins were registered at $4 \mathrm{~h}$ after UV-B irradiation. This finding might suggest that UV-B induced apoptosis was prevented through the modulation of these molecules, i.e. via reduction of Bax- $\alpha$ level and increase of $B c-X_{L}$ protein, enlightening some of the potential underlying mechanisms of this extract's protective effects (Fig. 1.). The CV extract's protective effect against UV-B-induced oxidative stress and apoptosis, evaluated through sunburn cells formation (Olteanu et al., 2012) and caspase 3 activity (Olteanu et al., 2014), were demonstrated earlier on SKH-1 nude mice and on endothelial cells, respectively. Also, the extract's preventive effect on the UVB-induced DNA lesions in HaCaT cells was previously established (Perde-Schrepler et al., 2011).

\section{Conclusion}

The CV extract used in the present study exerted protective effects on $\mathrm{HaCaT}$ cells subjected to minimal erythema dose of UV-B radiation, consisting in significant reduction of ROS production and prevention of apoptosis. These effects are concentration-dependent and time-dependent and, at least to a certain extent, are due to the modulation of $\mathrm{Bax}-\alpha$ and $\mathrm{Bcl}-\mathrm{X}_{\mathrm{L}}$ proteins. These results are in concordance to others in literature (Olteanu et al., 2012; Olteanu et al., 2014; Perde-Schrepler et al., 2011) and support further studies to identify other molecules and pathways whereby the CV extract may exert its beneficial protective effects. These findings also suggest that the $\mathrm{CV}$ extract could be used as a potential photoprotective agent.

\section{Acknowledgments}

This work was supported by the Executive Unit for Financing Higher Education, Research, Development and Innovation (UEFISCDI), Romania, Codes: 678/2013 and 250/2011. This paper was published under the frame of European Social Found, Human Resources Development Operational Programme 20072013, project no. POSDRU/159/1.5/138776.

\section{References}

Assefa Z, Van Laethem A, Garmyn M, Agostinis P (2005). Ultraviolet radiation-induced apoptosis in keratinocytes: On the role of cytosolic factors. Review. Biochimicaet Biophysica Acta 1755:90-106.

Boukamp P, Petrussevska RT, Breitkreutz D, Hornung J, Markham A, Fusening NE (1998). Normal keratinization in a spontaneously immortalized aneuploid human keratinocyte cell line. The Journal of Cell Biology 106:761-771.

Boya P, Gonzalez-Polo RA, Poncet D, Andreau K, Vieira HL, Roumier T, Perfettini JL, Kroemer G (2003). Mitochondrial membrane permeabilization is a crical step of lysosome-initated apoptosis induced byhydroxychloroquine. Oncogene 22:3927-3936.

David L, Moldovan B, Vulcu A, Olenic L, Perde-Schrepler M, FischerFodor E, Florea A, Crisan M, Chiorean I, Clichici S, Filip GA (2014). Green synthesis, characterization and anti-inflammatory activity of silver nanoparticles using European black elderberry fruits extract. Colloids and Surfaces B. Biointerfaces 122:767-77.

Dhumrongvaraporn A, Chanvorachote P (2013). Kinetics of ultraviolet B irradiation-mediated reactive oxygen species generation in human keratinocytes.Journal ofCosmetic Science 64:207-17. 
Filip A, Clichici S, Daicoviciu D, Catoi C, Bolfa P, Postescu ID, Gal AF, Baldea I, Gherman C, Muresan A (2011). Chemopreventive effects of Calluna vulgaris and Vitis vinifera extracts on UVB-induced skin damage in SKH-1 hairless mice. Journal of Physiology and Pharmacology 62:385-92.

Heck DE, Vetrano AM, Mariano TM, Laskin JD (2003). UVB light stimulates production of reactive oxygen species: unexpected role for catalase. Journal of Biological Chemistry 278: 22432-6.

Hockenbery DM, Oltvai ZN, Yin XM, Milliam CL, Korsmeyer SJ (1993). Bd-2 functions in an antioxidant pathway to prevent apoptosis. Cell 75:241-251.

InYoung K, Yu-Ying H (2014). Ultraviolet radiation-induced nonmelanoma skin cancer: Regulation of DNA damage repair and inflammation. Genes \& Diseases 1:188-198.

Janovska J, Voicehovska J, Kasparane L (2015). Sun induced skin damage and immunosuppression. Romanian Journal of Clinical and Experimental Dermatology 2(2):8490.

Juba BA, Sovrea A, Crisan D, Melincovici C, Coneac A, Badea M, Crisan M (2013). Apoptotic markers in photoinduced cutaneous carcinoma. Romanian Journal of Morphology and Embryology 54 (3 Suppl):741747.

Kane DJ, Sarafian TA, Anton R, Hahn H, Gralla EB, Valentine JS, Ord T, Bredesen DE (1993). Bcl-2 inhibition of neural death: decreased generation of reactive oxygen species. Science 262:1274-1277.

Krajevski S, Krajevska M, Shabaik A, Wang HG, Irie S, Fong L, Reed JS (1994). Immunohistochemical analysis of in vitro patterns of Bcl-X expression. Cancer Research 54:5501-5507.

Kulms D, Schwartz T (2002). Independent contribution of three different pathways to ultraviolet-B-induced apoptosis. Biochemical Pharmacology 64:837-841.

Lorencini M, Brohem CA, Dieamant GC, Zanchin NIT, Maibach HI (2014). Active ingredients against human epidermal aging. Ageing Research Reviews 15:100-115.

Masaki H, Izutsu Y, Yahagi S, Okano Y (2009). Reactive oxygen species in HaCaT keratinocytes after UVB irradiation are triggered by intracellular Ca2+ levels. Journal of Investigative Dermatology Symposium Proceedings 14:50-52.

Olteanu ED, Filip A, ClichiciS, Daicoviciu D, Achim M, Postescu ID, Bolfa P, Vlase I, Muresan A (2012). Photochemoprotective effect of Calluna vulgaris extract on skin exposed to multiple doses of ultraviolet $\mathrm{B}$ in SKH-1 hairless mice. Journal of Environmental Pathology and Toxicology 31:233-43.

Olteanu D, Baldea I, Clichici S, Bolfa P, Cenariu M, Screpler-Perde M, Alupei M, Muresan A, Filip A (2014). In vitro studies on the mechanisms involved in chemoprevention using Calluna vulgaris on vascular endothelial cells exposed to UVB. Photochemistry and Photobiology 136:5461.
Pathak MA, Fitzpatrick TB, Greiter F, Kraus EW (1987). In: Fitzpatrick TB, Eisen AZ, Wolff K, Freeberg IM, Austen KF (Eds). Preventive treatment of sunburn, dermatoheliosis, and skin cancer with sunprotective agents. McGraw-Hill BookNew York Copp 1507-1522.

Perde-Schrepler M, Chereches G, Brie I, Virag P, Barbos O, Soritau O, Tatomir C, Fischer-Fodor E, Filip GA, Vlase L, Postecu ID (2011). Photoprotective Effect of Calluna vulgaris Extract Against UVBInduced Phototoxicity in Human Immortalized Keratinocytes. Journal of Environmental Pathology and Toxicology 30:323-331.

Postescu ID, Tatomir C, Chereches G, Brie I, Petrisor D, Hosu AM, Miclaus V, Pop A (2007). Spectroscopic characterization of some grape extracts with potential role in tumor growth inhibition. Journal of Optoelectronics and Advanced Materials 9:564567.

Robbins RJ (2003). Phenolics acids in food: an overview of analytical methodology. Journal of Agricultural and Food Chemistry 51:28662887.

Ryu H-C, Kim C, Kim J-Y, Chung J-H, Kim J-H (2010). UVB radiation induces apoptosis in keratinocytes by activating a pathway linked to "BLT2-reactive oxygen species". Journal of Investigative Dermatology 130:1095-1106.

Salucci S, Burattini S, Curzi D, Buontempo F, Martelli AM, Zappia G, Falcieri E, Battistelli M (2014). Antioxidants in the prevention of UVBinduced keratynocyte apoptosis. Journal of Photochemistry and Photobiology B: Biology 141:1-9.

Sklar LR, Almutawa F, Lim HW, Hamzavi I (2013). Effects of ultraviolet radiation, visible light, and infrared radiation on erythema and pigmentation: a review. Photochemical \& Photobiological Sciences 12(1):5464.

Svobodova A, Psotova J, Walterova D (2003). Natural phenolics in the prevention of UV-induced skin damage. A review. Biomedical Papers147:137-145.

Sun S-Y (2010). N-acetylcysteine, reactive oxygen species and beyond. Cancer Biology \& Therapy 9:109-110.

Takahashi H, Honma M, Ishida-Yamamoto A, Namikawa K, Miwa A, Okado H, Kiyama H, lizuka H (2001). In vitro and in vivo transfer of bcl-2 gene into keratinocytes suppresses UVB-induced apoptosis. Photochemistry and Photobiology 74:579-586.

Zhao M, Eaton JW, Brunk UT (2000). Protection against oxidantmediated lysosomal rupture: a new anti-apoptotic activity of Bcl-2? FEBSLetters 485:104-108.

Wu MS, Sun DS, Lin YC, Cheng CL, Hung SC, Chen PK, Yang JH, Chang HH (2015). Nanodiamonds protect skin from ultraviolet Binduced damage in mice. Journal of Nanobiotechnology 13(1):1-12. 